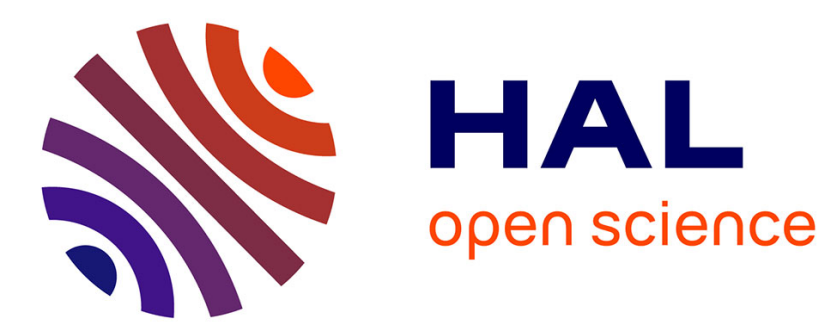

\title{
Natural balance of graminicolous aphids in Pakistan. Survey of populations \\ Sulaiman Hamid
}

\section{To cite this version:}

Sulaiman Hamid. Natural balance of graminicolous aphids in Pakistan. Survey of populations. Agronomie, 1983, 3 (7), pp.665-673. hal-00884557

\section{HAL Id: hal-00884557 https://hal.science/hal-00884557}

Submitted on 1 Jan 1983

HAL is a multi-disciplinary open access archive for the deposit and dissemination of scientific research documents, whether they are published or not. The documents may come from teaching and research institutions in France or abroad, or from public or private research centers.
L'archive ouverte pluridisciplinaire HAL, est destinée au dépôt et à la diffusion de documents scientifiques de niveau recherche, publiés ou non, émanant des établissements d'enseignement et de recherche français ou étrangers, des laboratoires publics ou privés. 


\title{
Natural balance of graminicolous aphids in Pakistan. Survey of populations
}

\author{
Sulaiman HAMID \\ Sind Sugar Industry Research Institute, 14-A, Latifabad III, Hyderabad Sind, Pakistan
}

Aphids attacking gramineous crops were studied in seven climatically and ecologically different regions of Pakistan. Forda formicaria Heyd., Melanaphis sacchari Zehnt., Myzus obtusirostris David, Narayanan and Rajasingh, Rhopalosiphum maidis Fitch, Rhopalosiphum padi L., Schizaphis graminum Rond., Sitobion avenae F. and Sipha maydis Pass. attacked economic grain crops. In turn these aphids were parasitized by Aphelinus spp., Aphidius colemani Viereck, Aphidius pascuorum Marshall, Aphidencyrtus aphidivora Meyr, Diaeretiella rapae M'Intosh, Ephedrus sp., Lysiphlebus arvicola Stary and Praon pakistanum Kirkland. On the other hand Anthocoris sp. and Orius sp. (Anthocoridae) ; Coccinella septempunctata L., Harmonia (Leis) dimidiata F., Hippodamia variegata Goeze, Menochilus sexmaculatus F., Oenopia sauzeti Muls., Scymnus (Pullus) guimeti Muls. and Scymnus nubilus Muls. (Coccinellidae); Episyrphus balteatus DeGeer, E. confrater Wied., E. corollae F. and E. menthastri L. (Syrphidae) ; Chrysopa carnea Stephens (Chrysopidae); and Leucopis sp. (Chamaemyildae) were the common predators throughout the study area.

Population studies conducted, on both summer and winter grain crops in different ecological and geographical conditions of Pakistan, indicate that these natural enemies occur in a definite sequence and play a significant role in maintaining a natural balance throughout the country.

Additional key words : Wheat, maize, sorghum, parasites, predators.

Les pucerons attaquant les graminées cultivées au Pakistan ont fait l'objet d'une étude dans 7 régions climatiquement et écologiquement différentes. Les. espèces Forda formicaria Heyd., Melanaphis sacchari Zehnt. Myzus obtusirostris David., Narayanan et Rajasingh, Schizaphis graminum Rond., Sitobion avenae F. et Sipha maydis Pass. constituent une menace économique pour la production de grains. Cependant, ces aphides sont parasités par Aphelinus sp., Aphidius colemani Viereck, Aphidius pascuorum Marshall, Aphidencyrtus aphidivora Meyr., Diaeretiella rapae M'Intosh, Ephedrus sp., Lysiphlebus arvicola Stary, et Praon pakistanum Kirkland. D'autre part, Anthocoris sp. et Orius sp. (Anthocoridae); Coccinella septempunctata L., Harmonia (Leis) Dimidiata F., Hippodamia variegata Goeze, Menochilus sexmaculatus F., Oenopia sauzeti Muls., Scymnus (Pullus) guimeti Muls. et Scymnus nubilus Muls. (Coccinellidae) ; Episyrphus balteatus De Geer, E. confrater Wied., E. corollae F. et E. menthastri L. (Syrphidae) ; Chrysopa carnea Steph. (Chrysopidae) et Leucopis sp. (Chamaemyidae) sont des prédateurs communément rencontrés dans l'aire étudiée.

Les études de population qui ont été conduites, à la fois sur des céréales de printemps et d'automne dans différentes situations écologiques et géographiques au Pakistan, montrent que ces ennemis naturels surviennent dans un ordre parfaitement défini et qu'ils jouent un rôle significatif en maintenant un équilibre naturel dans tout le pays.

Mots clés additionnels : Blé, maïs, sorgho, parasites, prédateurs.

\section{INTRODUCTION}

Aphids are serious pests of gramineous crops in temperate regions. In the United States of America the green-bug, Schizaphis graminum Rond. has recently taken a heavy toll of winter-grown small grains in the central and southwestern states (JACKSON et al., 1971); it has severely damaged wheat crops in the central and eastern states
(KLOSTERMEYER, 1972) and was a major problem on sorghum in midwestern and western states (WALKER et al., 1973). Since wheat and sorghum are native to the Oriental and Ethiopian regions where populations of some of the common aphids, including the greenbug, remain at low levels, it seemed logical to investigate both biotic and abiotic factors responsible for maintaining the natural balance in graminicolous aphid populations in these regions. 
However, in Pakistan, low-yielding native varieties of wheat are being replaced with high-yielding varieties developed from crosses with Mexican strains, while new hybrids of sorghum and maize have been introduced from the U.S.A. These new varieties with different characteristics present new situations for aphids and may therefore create new problems. Comparative population studies on aphids and their natural enemies under these changing conditions will be of value in any planning of future developments. Thus, with this view, investigations on the natural balance of graminicolous aphids in Pakistan were undertaken and 8 species of aphids with their natural enemies were studied.

The taxonomy, biology and general ecology of the Middle East Aphidoidea is well documented (BODENHEIMER \& SwIRSKI, 1957). Distribution maps of Schizaphis (Toxoptera) graminum Rond. (ANONYME, 1963), Sitobion (Macrosiphum) avenae (granarium) F. (ANONYME, 1965), Rhopalosiphum maidis Fitch (ANONYME, 1971a) and Rhopalosiphum padi L. (ANONYME, 1971b) have already been published.

In the Indo-Pakistan subcontinent, LEFROY (1909) was the first to report $M$. granarium (S. avenae) on wheat. DAS (1918) gave a consolidated account of the Aphididae of Lahore mentioning $R$. (Aphis) maidis Fitch, Melanaphis (A.) sacchari Zehnt., M. granarium, S. (Siphocoryne) avenae Fabr. and $T$. graminum from wheat, barley, oats, sorghum and maize. GEORGE (1928) reported $A$. maidis on sorghum and maize and Forda orientalis sp. n. on the roots of sorghum from southern India with special reference to those of Coimbatore. UlLAH (1940) recorded $A$. maidis, $M$. granarium and $T$. graminum on sorghum and wheat from Delhi. SHARMA \& BHALLA (1964), while reporting a survey in Himachal Pradesh, mentioned Macrosiphum (Sitobion) avenae Fabr. and $M$. (S.) eleusines Theobald i.e. Sitobion miscanthi Takahashi on wheat and $R$. maidis on barley and wheat.

With regard to the natural enemies occurring in IndoPakistan, Subramaniam (1924) reported 37 common coccinellid predators occurring on aphids in southern India. BHATIA \& SHAFFI (1933) reported the life-histories of some important Indian Syrphidae. CHERIAN (1933) briefly described all stages of an agromyzid, Leucopis sp., which were collected with aphids on sorghum, cotton, Pennisetum typhoides (Burm. f.) Stapf and Dolichos lablab L. in Madras. RAHMAN (1940) furnished a list of 33 important predators with short notes on life histories, hosts and parasites which included graminicolous aphids and some common predators. PRUTHI (1942) reported that Chilomones (Menochilus) sexmaculatus F. preferred $S$. avenae to any other species of aphid and a single individual destroyed on an average 44 aphids per day. KAPUR (1942) worked out the distribution, seasonal history, feeding records and possibilities of mass-production of Hippodamia (Adonia) variegata Goeze, Brumoides (Brumus) suturalis F, and Scymnus quadrillum Motsch. PuTtaRudriaH \& CHANNA BASAVANNA (1958) provided a list of 35 aphid predators that occur in Mysore. NARAYANAN et al. (1960) formulated a catalogue of the known species of the world belonging to the subfamily Aphididiinae which included some important parasites of graminicolous aphids. ALAM \& HAFIZ (1963) presented a list of some 23 species of parasites and 14 species of predators for 43 aphid hosts in Pakistan. KISHAN \& SHUKLA (1966) recorded a Braconid parasite for $M$. (Longiunguis) sacchari while KASI VISWANATHAN (1972) recorded Aphidius transcaspicus (Telenga) as a parasite of $R$. maidis. In the meanwhile KHAN \& YUNUS (1970) reported on the biology of Episyrphus (Syrphus) balteatus DeGeer.
With the advances in the studies of population dynamics and their applications in biological control, it is becoming more and more essential to study aphid behaviour with special reference to the host-plant relationship and to evaluate actions and reactions of the natural forces working in favour and against the aphid population in connection with individual species involved. Such studies are particularly needed in Pakistan where low-yielding varieties are being replaced with foreign high-yielding varieties and new pest problems could be created in the future. This study is an effort towards this goal.

\section{METHODS}

Surveys were carried out during 1972-76 in the western hills (Parachinar), the northern hills (Swat valley-Mingora, Singota, Behrain and Kalam), the Peshawar valley (Peshawar and Kohat), the foot-hills (Rawalpindi), the plains (Lyallpur now Faisalabad), the semi-desert (Multan) and the sub-coastal (Hyderabad) areas. These areas were chosen to include most of the ecological and climatic conditions under which gramineous crops are grown in Pakistan (figure 1).

A sample of 50 plants from 5 different points in a field (10 plants each from the 4 corners and 10 from the center) was randomly picked. It is to this sample size that all the information is related. For this purpose a minimum sample size for comparing aphid population was pre-determined at 30 plants level, when only $2 \%$ of the plants were infested at Rawalpindi. In all, 5 replicates were examined. The mean number of aphids at the 30 plant level was compared with the mean number at 100 plants. This comparison resulted in a similar arithmetic mean with a standard deviation of \pm 2.65 and, further addition of plants to this sample of 30 plants made no difference in the mean aphid population.

\section{SURVEY}

Observations are listed (table 1) on the distribution, host-plants, degree of infestation and parasites of 8 aphid species, Forda formicaria Heyd., S. avenae, Melanaphis sacchari Zehnt., Myzus obtusirostris David, Narayanan and Rajasingh, Rhopalosiphum maidis Fitch, $R$. padi L., $S$. graminum and Sipha maydis Pass., attacking the economic grain crops recorded during this study.

Anthocoris sp., and Orius sp. (Anthocoridae) ; Coccinella septempunctata L., Harmonia (Leis) dimidiata (F.), $H$. variegata, $M$. sexmaculatus, Oenopia sauzeti Muls., Scymnus (Pullus) guimeti Muls., and S. nubilus Muls., (Coccinellidae); E. balteatus (DeGeer), E. confrater (Wied.), E. corollae F., and E. menthastri L. (Syrphidae); Chrysopa carnea Stephens (Chrysopidae); and Leucopis sp. (Chamaemyiidae) were the common polyphagous predators throughout the study area.

At the beginning of this research a preliminary survey, started in February, was conducted in all the areas. Both the alate and apterous females of $S$. avenae and $S$. graminum and a few of $R$. padi and $S$. maydis were collected in the samples taken from 22 selected fields of imported varieties, crosses between Mexican and Pakistani varieties ('Mexipak', 'Chenab-70', 'Barani-70', 'S.A. 42' and ' Khushal - 69') and local strains of wheat 'C 591' and ' C 518' with and without fertilizer application in various ecological regions of Pakistan. 


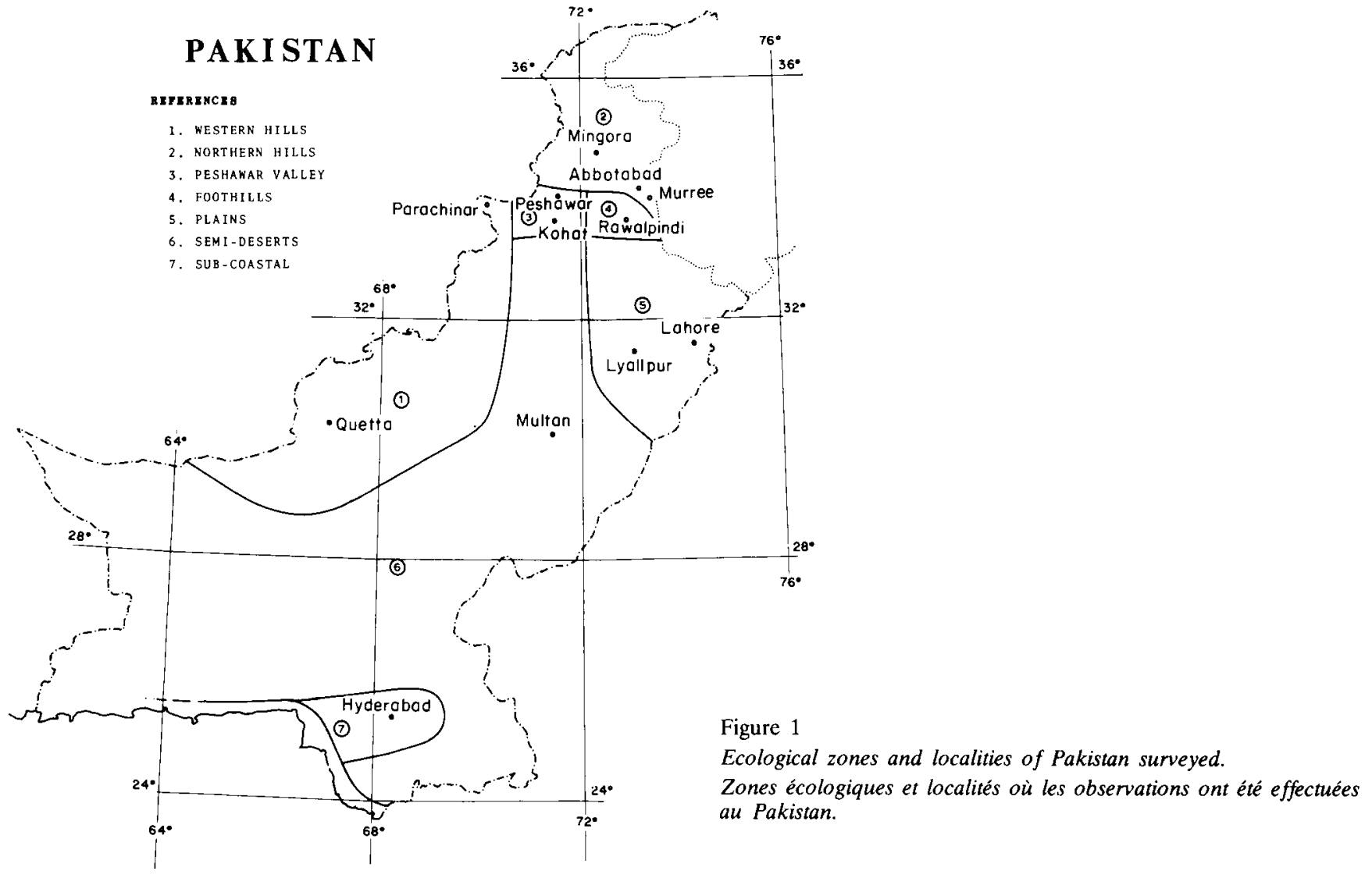

TABLE 1

Distribution, host plants, degree of infestation and parasites of graminicolous aphids in Pakistan.

Distribution, plantes-hôtes, degré d'infestation et parasites des pucerons des céréales au Pakistan.

\begin{tabular}{|c|c|c|c|c|c|}
\hline Aphid species & $\begin{array}{l}\text { Ecological } \\
\text { zones }\end{array}$ & $\begin{array}{l}\text { Host } \\
\text { plants }\end{array}$ & \multicolumn{2}{|c|}{$\begin{array}{l}\text { Degree of } \\
\text { infestation }\end{array}$} & Parasites \\
\hline $\begin{array}{l}\text { Forda } \\
\text { formicaria }\end{array}$ & Wh & sorghum & \multicolumn{2}{|l|}{+} & \\
\hline $\begin{array}{l}\text { Melanaphis } \\
\text { sacchari }\end{array}$ & $\begin{array}{l}\text { Wh, Pv, Fh, } \\
\text { P, Sd \& Sc }\end{array}$ & sorghum & \multicolumn{2}{|l|}{++} & Aphelinus sp. \\
\hline $\begin{array}{l}\text { Myzus } \\
\text { obtusirostris }\end{array}$ & $\mathrm{Nh}$ & maize & \multicolumn{2}{|l|}{+} & $\begin{array}{l}\text { Lysiphlebus } \\
\text { arvicola }\end{array}$ \\
\hline $\begin{array}{l}\text { Rhopalosiphum } \\
\text { maidis }\end{array}$ & Wh \& Nh & $\begin{array}{l}\text { wheat \& } \\
\text { sorghum }\end{array}$ & \multicolumn{2}{|l|}{+} & $\begin{array}{l}\text { Ephedrus sp. } \\
\text { L. arvicola } \\
\text { Toxares shigai }\end{array}$ \\
\hline $\begin{array}{l}\text { Rhopalosiphum } \\
\text { padi }\end{array}$ & $\begin{array}{l}\text { Wh, Nh, } \\
\text { Pv, Fh }\end{array}$ & $\begin{array}{l}\text { wheat \& } \\
\text { maize }\end{array}$ & \multicolumn{2}{|l|}{+} & $\begin{array}{l}\text { Ephedrus sp. } \\
\text { Aphidius colemani } \\
\text { Praon pakistanum }\end{array}$ \\
\hline $\begin{array}{l}\text { Schizaphis } \\
\text { graminum }\end{array}$ & $\begin{array}{l}\text { Wh, Nh, } \\
\text { Pv, Fh, P, } \\
\text { Sd \& Sc }\end{array}$ & $\begin{array}{l}\text { wheat } \\
\text { barley \& } \\
\text { sorghum }\end{array}$ & $\begin{array}{l}+++ \\
++ \\
+\end{array}$ & $\begin{array}{l}(\mathrm{Wh}) \\
(\mathrm{Nh}, \mathrm{Pv} \\
\mathrm{Fh}) \\
\quad(\mathrm{P}, \mathrm{Sd} \\
\quad \mathrm{Sc})\end{array}$ & $\begin{array}{l}\text { A. colemani } \\
\text { P. pakistanum } \\
\text { Diaeretiella rapae } \\
\text { Aphidencyrtus aphidivorus } \\
\text { Aphelinus sp. nr. maidis }\end{array}$ \\
\hline $\begin{array}{l}\text { Sipha } \\
\text { maydis }\end{array}$ & $\begin{array}{l}\text { Wh, Nh, Pv, } \\
\text { Fh, P, Sd \& } \\
\text { Sc }\end{array}$ & $\begin{array}{l}\text { wheat } \\
\text { barley, } \\
\text { sorghum } \\
\text { \&maize }\end{array}$ & $\begin{array}{l}++ \\
+++\end{array}$ & $\begin{array}{l}\text { (and } \\
\text { on fod- } \\
\text { der crops) }\end{array}$ & $\begin{array}{l}\text { D. rapae } \\
\text { Aphelinus sp. } \\
\text { Praon sp. }\end{array}$ \\
\hline $\begin{array}{l}\text { Sitobion } \\
\text { avenae }\end{array}$ & $\begin{array}{l}\text { Wh, Nh, Pv } \\
\text { Fh, P, Sd } \\
\& \text { Sc }\end{array}$ & $\begin{array}{l}\text { wheat \& } \\
\text { barley }\end{array}$ & $\begin{array}{l}+++ \\
++ \\
+\end{array}$ & $\begin{array}{l}(\mathrm{Wh}, \mathrm{Nh}) \\
(\mathrm{Pv}, \mathrm{Fh}) \\
(\mathrm{P}, \mathrm{Sd}, \mathrm{Sc})\end{array}$ & Aphidius pascuorum \\
\hline \multicolumn{3}{|c|}{$\begin{array}{l}\text { Wh, Western hills ; } \\
\text { Pv, Peshawar valley; } \\
\text { P Plains ; } \\
\text { Sc, Sub-coastal areas ; } \\
++, \text { Population below economic threshold }\end{array}$} & \multicolumn{3}{|c|}{$\begin{array}{l}\text { Nh, Northern hills; } \\
\text { Fh, Foothills; } \\
\text { Sd, Semi-deserts; } \\
+, \text { Negligible population ; } \\
+++ \text {, Locally damaging populations. }\end{array}$} \\
\hline
\end{tabular}


Winter wheat is grown from October to Junc in some of the areas surveyed. In general, sowing dates are the same throughout, but harvest times differ. Population peaks of $S$. graminum occurred during May in the hills and in March elsewhere, but those of $S$. avenae occurred just a month before harvest. VEREIJKEN (1979) reported that $S$. avenae multiplicd twice as rapidly on ear heads as on flag leaves. Owing, perhaps, due to the long favcurable period when the host plant was available, the maximum density of $S$. avenae was attained in the western hills. Densities were lowest in the plains (fig. 2).

DANIELS \& PORTER (1956) reported that high nitrogen levels in the soil and increased plant vigour result in high greenbug populations. In the present studies populations were higher in ficlds with fertilizer application. Thus during February, March and April 8.0,12.7 and 2.4 aphids per 100 plants were present in fields with fertilizer application as against $2.9,6.7$ and 0.2 aphids respectively, for those fields which did not receive any fertilizer.

'Mexipak' was the most commonly grown variety throughout the study area, while other varieties were restricted to some localities only. On the whole, population densities of $S$. graminum were higher on 'Mexipak' as compared with other varieties (table 2 ).
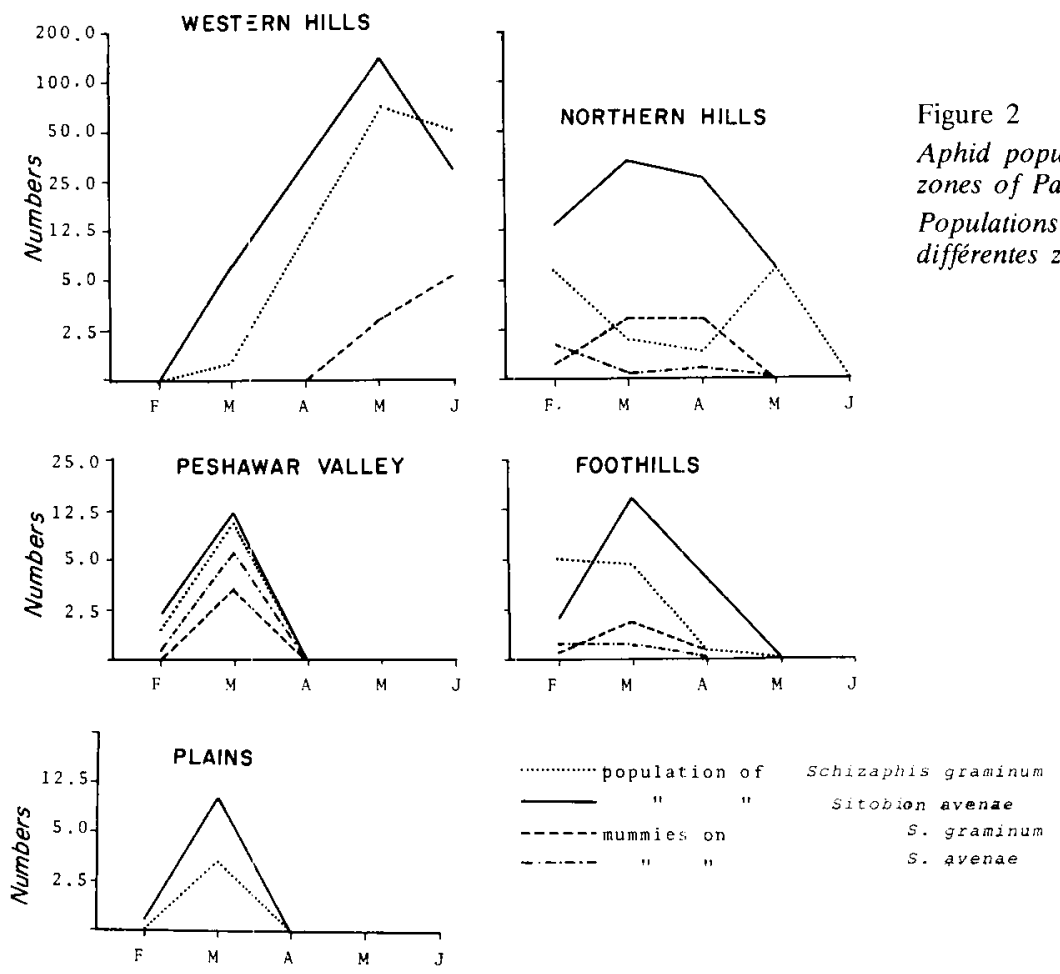

TABLE 2

Population density and parasitism (\%) of Schizaphis graminum on "Mexipak" and other varieties of wheat (1972). Densité de population et pourcentage de parasitisme de Schizaphis graminum sur la variété Mexipak et d'autres variétés de blé (1972).

\begin{tabular}{l|c|c|c|c}
\hline \multirow{2}{*}{ Months } & \multicolumn{2}{|c|}{ Mexipak } & \multicolumn{2}{c}{ Other Varieties } \\
& \multicolumn{1}{|c|}{$\begin{array}{c}\text { Aphids per } \\
100 \text { plants }\end{array}$} & $\begin{array}{c}\text { Parasitism } \\
\%\end{array}$ & $\begin{array}{c}\text { Aphids per } \\
100 \text { plants }\end{array}$ & $\begin{array}{c}\text { Parasitism } \\
\%\end{array}$ \\
\cline { 2 - 5 } & 8.5 & 21.1 & 1.6 & 25.0 \\
Feb. & 10.1 & 19.7 & 8.7 & 41.6 \\
Mar. & 2.0 & 40.0 & 0.0 & 0.0 \\
Apr. & 35.5 & 0.0 & 94.0 & 0.0 \\
May & 186.0 & 0.0 & 16.0 & 0.0 \\
Jun. & & & & \\
\hline
\end{tabular}

The effect, if any, due to fertilizer application and also due to host plant differences between varieties was not measurable in ficld populations of $S$. avenae.

Aphidius colemani Viereck, Diaeretiella rapae M'Intosh, Praon pakistanum Kirkland and Aphidencyrtus aphidivorus Meyr. attacked the greenbug ( $S$. graminum) in that order of both importance and sequence. There was no regular pattern of parasitism. It was generally highest during March in the Peshawar valley (fig. 3 ) where the first 3 parasites were active. Parasitism was not encountered in samples from the western hills or the plains. $A$. aphidivorus occurred only once in the northern hills, during April. Parasitism during February and March was lower on Mexican wheat than on other varieties (table 2). The high parasitism (40\%) by $A$. aphidivorus in April appears to be a consequence of the low aphid population, although this parasite had not been recorded during the previous 2 months. main parasites occurring throughout the study area except the plains. Incidence of parasitism followed the same trend as that of the aphid populations (fig. 2). A. aphidivorus also attacked $S$. graminum in May in the western hills and, in April in the foothills, parasitism was, however, negligible.

During summer (June) till fall, $S$. avenae, $S$. graminum

Figure 2

Aphid populations on wheat (per 50 plants) in different ecological zones of Pakistan (1972).

Populations de pucerons dénombrées sur 50 plants de blé dans différentes zones écologiques du Pakistan (1972).
A. colemani and Aphidius pascuorum Marshall were the 
and $R$. padi attacked spring wheat in the Kaghan valley. The greenbug along with $M$. sacchari, $S$. maydis and $R$. maidis, had shifted to Sorghum spp. at Parachinar. Maize was attacked by $M$. obtusirostris and $S$. maydis in different localities in the northern hills. From October till March $S$. avenae, $S$. graminum and $S$. maydis attacked cereals in the Swat valley. These species together with $R$. padi occurred on wheat in Hyderabad (sub-coastal) areas. These populations and their natural enemies were studied in detail (Population studies).

By October 'volunteer' wheat near threshing yards at Parachinar had sprouted and the aphid had shifted to these plants after living on sorghum during the summer months. By January winged forms of $S$. avenae and $S$. graminum were seen in all the areas studied. As also mentioned by MITTLER (1973), the maturity of the crop, the crowding of aphids, shortening of days and lower temperatures stimulated wing formation. Subsequently the winds during January from the northern and western hills helped their dispersal to the entire study area. The role of wind currents in aphid dispersal has been described in detail (JOHNSON, 1969).

Aphids were present near a threshing yard at Parachinar even after snow-fall in December, and were also collected from under snow in January. Both $S$. avenae and $S$. graminum survived the extreme cold conditions in these parts of Pakistan.

\section{POPULATION STUDIES}

\section{A. Summer crops}

\section{Sorghum (Parachinar)}

The greenbug collected on wheat in snowfall conditions during December (1972), at Parachinar, also attacked Sorghum halepense (L.) Pers., which is an abundant weed in that region during the summer. Populations based on counts from 50 randomly picked plants, at monthly intervals, from June to November (1973), were studied on grain sorghum cultivated for this purpose:

$S$. graminum was the first to appear and attacked $4.4 \%$ plants in June (fig. 3). M. sacchari and S. maydis appeared in July raising the total aphid population to 170 and infested plants to $15 \%$, although by this time the $S$. graminum population had declined a little. Since the amount of predation by syrphids was highest during July the percentage of infested plants fell slightly during August, despite the fact that the total aphid population $(3,650)$ had increased considerably. Since aphids provide a dominant stimulus in syrphid oviposition (CHANDLER, 1966), it appeared that the plants on which the majority of syrphids occurred during July-August were completely cleaned of aphids. The aphid populations on those plants which escaped syrphid oviposition had increased unchecked, leading to the general lowering of the infested plants. Parasitism also started in August and continued till November, but it was almost insignificant. $M$. sacchari $(3,970), S$. maydis $(1,850)$ and $S$. graminum (200) attained their peak populations in September, after which there was a general decline due to seasonal change and maturity of the crop. Since plants started dryingoff late in September, very few growing buds on which aphids could survive and reproduce were available in
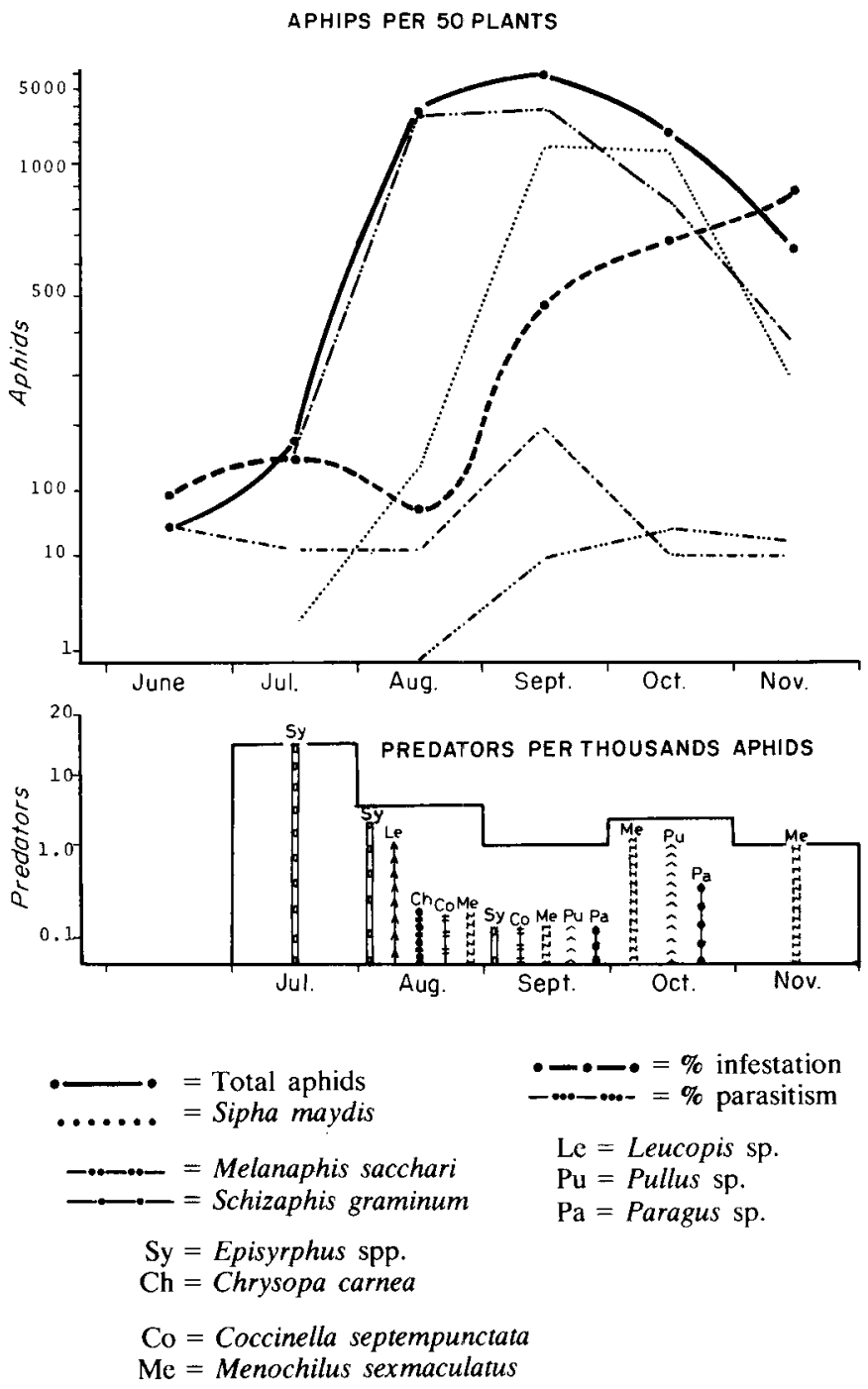

$\bullet-\bullet=\%$ infestation

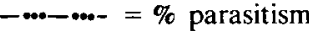

Le $=$ Leucopis sp.

$\mathrm{Pu}=$ Pullus sp.

$\mathrm{Pa}=$ Paragus sp.

$\mathrm{Me}=$ Menochilus sexmaculatus

Figure 3

Aphid and predator populations on sorghum at Parachinar (1973). Populations d'aphides et de prédateurs observées sur sorgho à Parachinar (1973).

October and still fewer in November. Thus, the aphid populations, confined to fewer green parts of the plants, became distributed over a large number of drying plants in October and November. Perhaps as a result of this, the percentage of infested plants increased considerably.

Predators, all of which were polyphagous, followed a very definite sequence of attack on these aphids : syrphids were the first to appear, in July, and continued for 3 months, with a gradual decline in their population. Leucopis sp. and $C$. carnea followed, but were active only during August. $C$. septempunctata occurred during August and September, while Scymnus sp. and Paragus sp. were present during September and October. Apart from these, M. sexmaculatus had the longest spell right from August till November with a gradual increase in its population.

Population fluctuations in the aphids appeared to be much influenced by the physiological and chemical state of the plant changing with age and the season. The average population was 120 aphids per plant at the peak infestation period during September. The population per plant was apparently below the economic level of injury. This may be attributed partly to the action of predators. 


\section{Other observations}

Apart from the localities regularly surveyed, $M$. sacchari and $S$. maydis were collected on maize and sorghum from all the areas of Pakistan. A sizeable population also occurred on individual plants in some areas. Under such conditions, $M$. sacchari was more common on sorghum and $S$. maydis on male spikes of maize. Aphelinus sp. was the only parasite which occurred throughout the country in the summer months and was common to both aphid species. All the predators, occurring in different localities in the hills, were also encountered along with these aphids in the rest of the country but syrphids and $M$. sexmaculatus were more common. $F$. formicaria was once collected from sorghum roots at Quetta (western hills).

\section{B. Winter crop}

Aphid populations attacking wheat were also studied in the Swat valley $(1,000-1,200 \mathrm{~m})$ in the northern hills and at Hyderabad $(30 \mathrm{~m})$ in southern Pakistan. Samples of 50 plants were taken.

\section{Wheat (Swat)}

Populations were studied in the Swat valley at Mingora, Singota and Behrain (within the radius of 30 kilometres of Mingora) (fig. 4). On the whole, in November (1976), $5 \%$ of the plants with an average population of $2 S$. avenae and $10 \mathrm{~S}$. graminum occurred. Both the number of infested plants and the aphid population increased from December till April. Infestation was $9 \%$ with $8 S$. avenae and $7 S$. graminum in December; it was $12 \%$ with 30 and 10 in January ; $18 \%$ with 120 and 30 in February ; $21 \%$ with 125 and 50 in March and $32 \%$ with 112 and 9 in April, respectively. In addition to these $19 \mathrm{~S}$. maydis were collected at Singota during March. Higher (though not damaging) populations occurred during March and April, after which these declined abruptly with the maturity of the plants. Parasitism by $A$. colemani varied from 1 to $16 \%$ with an overall average of $5 \%$ and the parasite was active from the very onset of infestation. However, even a smaller degree of parasitism in the early stages of a pest multiplying in geometric progression has a much more long lasting checking effect than it apparently appears to contribute. During February and March, when populations were comparatively high, the predator syrphids, Leucopis sp., $C$. carnea, $C$. septempunctata and $M$. sexmaculatus were additional natural enemies of important consequence.

\section{Wheat (Hyderabad)}

Aphids were not found in November (1975) ; infestation was $8 \%$ with $7 R$. padi and $285 S$. maydis, in December ; with the same infestation, populations of $R$. padi increased to 136 whilst $S$. maydis decreased to 98 in January and $S$. graminum (5) appeared for the first time (fig. 5). Infestation increased to $12 \%$ with $61 \mathrm{R}$. padi, $27 \mathrm{~S}$. maydis, $72 \mathrm{~S}$. graminum with the addition of $8 S$. avenae in February. Infestation then declined to $5 \%$ with $35 \mathrm{~S}$. graminum only during March. The crop was harvested in April. The highest populations were of $S$. maydis during December, though the number of species occurring on wheat increased in latter months, the total population decreased.

$M$. sexmaculatus, remained active throughout the period, Leucopis sp. appeared in December. C. septempunctata and
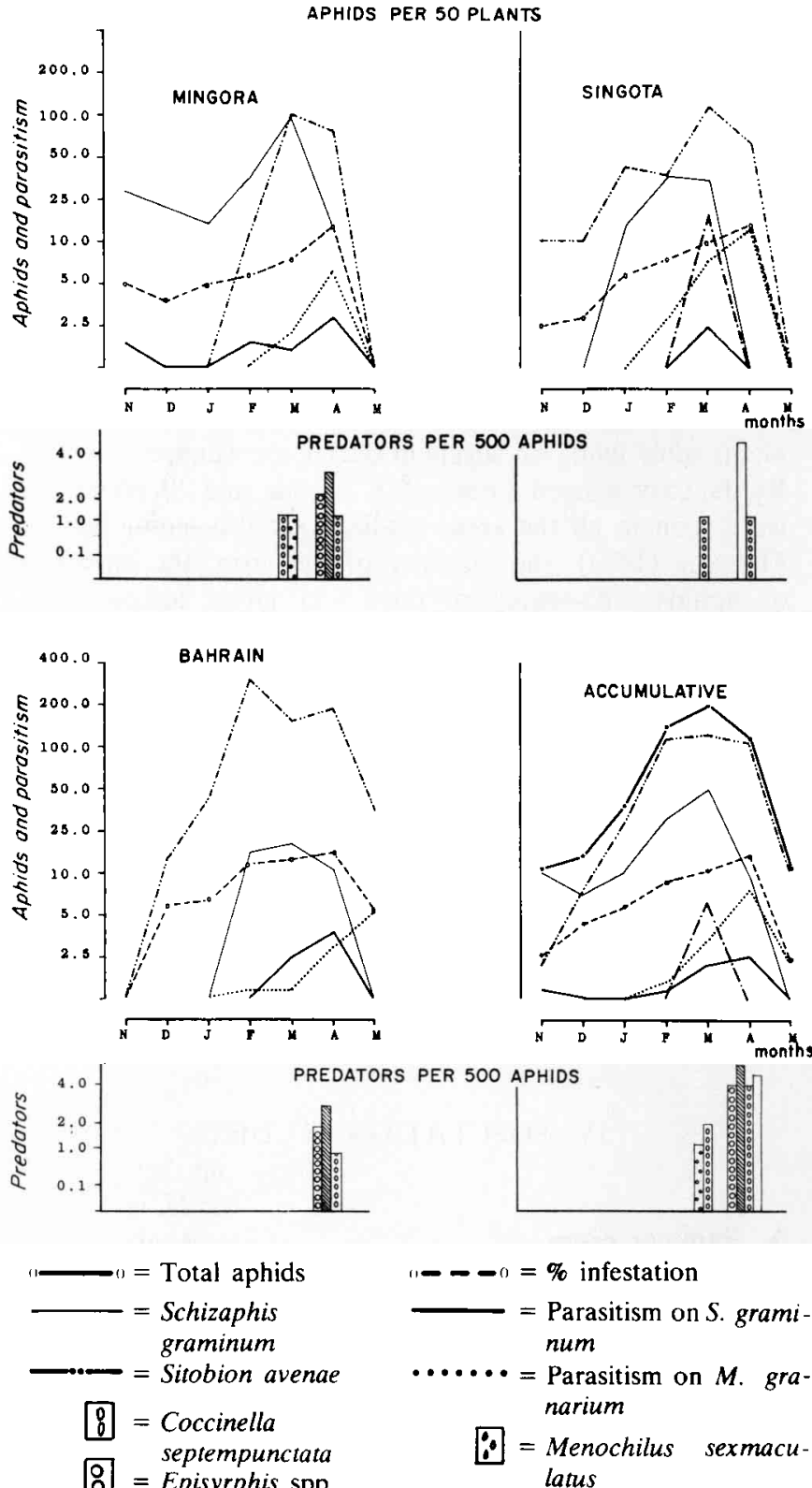
num

.... = Parasitism on $M$. granarium

$:$ = Menochilus sexmacu latus

$Q=$ Leucopis sp.

$\square=$ Chrysopa carnea

Figure 4

Aphid and predator populations on winter wheat in Swat (1976). Populations d'aphides et de prédateurs observées sur blé d'hiver à Swat (1976).

C. carnea occurred during February and March, and $B$. suturalis during March. Parasitism by Aphidius sp. was noticed in $12 \% \mathrm{~S}$. graminum only during March.

At this locality aphid populations were very low, with a sufficient number of natural enemies appearing in a very definite sequence to keep them in check.

\section{DISCUSSION AND CONCLUSION}

Until these studies were made, only 5 species of aphids were reported from gramineous crops in Pakistan. There were rather confusing records of 4 parasite species that attacked these aphids. Although a large number of preda- 

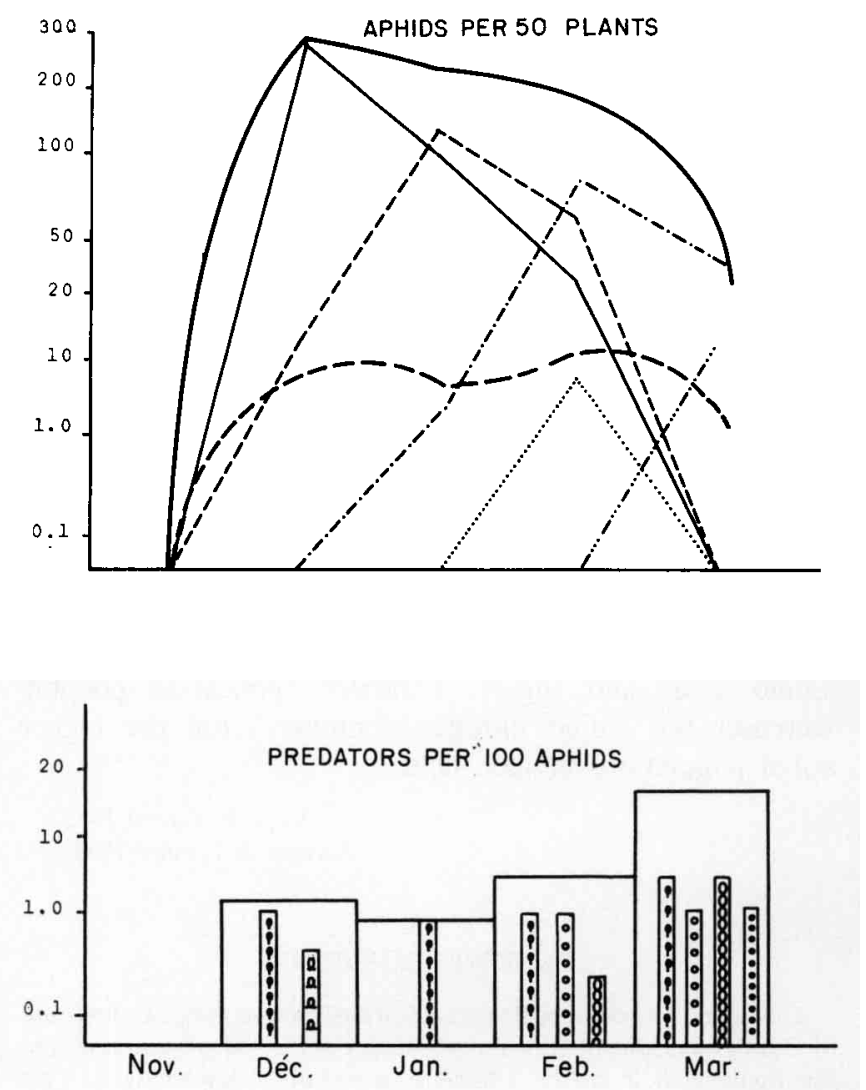

tory species were listed, little was known about their control potential and only a few short notes existed on $H$. variegata, $B$. suturalis and $S$. quadrillum. As a result of present investigations, the biotic and abiotic factors that are responsible for population fluctuations of 7 aphid species occurring regularly on economic grain crops in Pakistan have been reported for the first time. Also, for the first time it has been shown that life cycles of these graminicolous aphids are affected by host suitability, host change, varietal susceptibility, temperature and snowfall. Detailed studies on 8 species of parasites attacking these aphids in different parts of Pakistan, their role in population regulation, host preferences and host abundance, have added to the knowledge of parasite associations with the aphid fauna of gramineous crops. Two of these parasite species are new to science. Studies on parasite numbers $A$. colemani and $P$. pakistanum in relation to host densities and control potential of 6 predatory species are also new. Since the Gramineae are native to the Ethopian and Oriental regions and the aphid populations remain in check in Pakistan, these investigations have a unique comparative value for the regions where gramineous aphids lack the desired natural balance. In the following discussion, an attempt is therefore made to evaluate the usefulness of these investigations.

In Pakistan aphid populations are usually low, in contrast with the United States of America where large aphid populations, particularly those of the $S$. graminum, infest grain crops. The number of parasitic species Lysaphidus platensis Brethes, Lysiphlebus testaceipes Cresson, Monoctonus sp. (MACKAUER \& STARY, 1967), D. rapae (WALKER et al., 1973), Aphelinus nigritus Howard (ARCHER $e_{i}^{t}$ al., 1974) and Aphelinus asychis Walker, introduced from Iran into the USA in 1971, (JACKSON et al., 1971) occurring on the greenbug in the USA are no less than the number of species occurring in Pakistan: This is also true of the insect

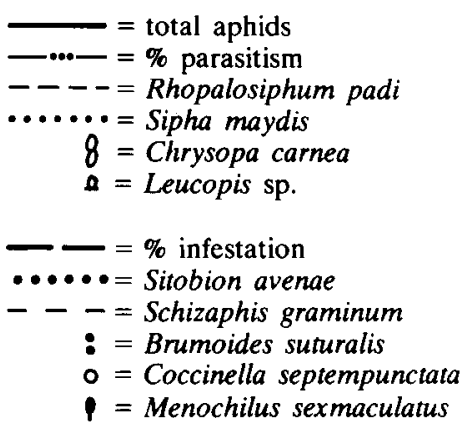

Figure 5

Aphid and predator populations on winter wheat in Hyderabad (1975).

Populations d'aphides et de prédateurs observées sur blé d'hiver à Hyderabad (1975).

predators. Recently excellent control of the greenbug in Oklahoma by means of a spider Phidippus audax Hentz has been demonstrated (MUNIAPPAN \& CHADA, 1970). It is evident that in Pakistan, apart from natural enemies, other environmental factors are equally effective in preventing growth of aphid populations.

Mixed cultivation is practiced far more frequently in Pakistan than in the USA where large areas of monocultures are common. Monocultures provide ideal conditions for pest dispersal, and mixed cultivation is helpful in conservation of natural complex. In Pakistan grain crops are generally grown in habitats surrounded by other vegetables and orchards and the aphids attacking these crops occur in the same general habitat as mealy-bugs, scales and cicadellids. Hence polyphagous natural enemies have other hosts to feed on in addition to the aphids, rather than being forced to migrate in search of food when these aphids are scarce as is common in monoculture. Hence, these cultural practices provide ideal situation for the natural enemies to survive and generally to keep the aphid populations below economic threshold levels.

On winter wheat $S$. avenae was the dominant aphid followed by $S$. graminum while $R$. maidis, $R$. padi and $S$. maydis were comparatively rare. As experimentally determined, the average rate of reproduction of $S$. graminum was almost 4 times that of $S$. avenae, yet the populations of the latter were almost double (HAMID, 1979). From what has so far been observed, 2 factors appeared to have contributed to this : (a) initial populations of $S$. avenae during February were higher than those of $S$. graminum in all localities except the foothills. Such a difference at the beginning of the season could be responsible for substantial differences in the later stages ; (b) the more diverse parasite complex and comparatively higher rate of parasitism of $S$. graminum than on $S$. avenae. 
In Pakistan, alate viviparae of $S$, avenae and $S$. graminum were seen on wheat and barley during the fall in the hills, foot-hills and plains. This phase of aerial dispersal indicated a weak point in the infestation cycle as both the static and migrating populations were low. At this time $M$. sexmaculatus, Scymnus sp. and Paragus sp. were active on the aphids attacking sorghum at Parachinar and $M$. sexmaculatus, $C$. septempunctata and $H$. variegata adults on spring wheat at Kaghan (HAMID, 1979). Since these predators helped in curtailing the aphid population at a critical time they were of special significance. Of these predators, $M$. sexmaculatus was the most important as it remained active until snowfall - yet another even more precarious phase in the scasonal cycle of the aphids.

The population surviving the snowfall and migrants leaving the hills in the fall attacked wheat and barley in the foot-hills and plains and were in turn the hosts of a number of braconid parasites of which $A$. colemani and $P$. pakistanum were important. Nothing is known about the likely dispersal of these aphids back to the hills at the end of the season and in all probability they die out after the cereal harvest in the foothills, Preshawar valley, plains, semi deserts and sub-coastal areas as a result of high temperatures, whereas the cycle continues in the hills. S. graminum and $S$. avenae shifted to spring wheat in the Kaghan valley and the former to sorghum at Parachinar in June. In both these situations $E$. balteatus followed by $C$. carnea and Leucopis sp. were the earliest predators to arrive and these were consequently important in limiting the initial build-up of aphid populations. Although a number of other predators preyed upon these aphids, syrphids stayed longest in the Kaghan valley (HAMID, 1979). However, the period of activity of $M$. sexmaculatus was longest in Parachinar.

Population studies conducted in the sub-coastal areas also indicated that amongst natural enemies attacking $S$. avenae, $R$. padi, S. graminum and $S$. maydis on wheat, $M$. sexmaculatus was the only predator which remained active throughout the growing season, adding to its value as control agent.

The populations of $S$. graminum, $M$. sacchari, $S$. maydis on sorghum at Parachinar, after attaining an early peak declined during the remaining period of the crops. This may be attributed to the cumulative effects of climatic changes due to approaching winter, and the maturing of the plants both resulting in a slowing down of the flow of sap in the plant. Parasites were not important but predators appeared to play a substantial role in keeping the populations at relatively low levels.

S. graminum populations were higher in fields where fertilizer had been applied. These findings are similar to those of MALTAIS (1951) : namely that the nitrogen content of whole plant samples and also of water extracts was higher for a susceptible variety than for resistant ones. aphids require soluble food and most of the solutes in plants are amino acids and sugars. Fertilizer application possibly increases the amino nitrogen content, hence the higher aphid populations in such fields.

Reçu le 6 avril 1982 Accepté le 8 mars 1983.

\section{ACKNOWLEDGEMENTS}

This work was done at Pakistan Station, Commonwealth Institute of Biological Control Rawalpindi, under a PL-480 programme and the financial help of the USDA is gratefully acknowledged. This rescarch also formed a portion of Ph.D. thesis of Quaid-i-Azam University under the supervision of Dr. J. IOBAL and I am indebted for his help throughout this work. I am also thankful to Dr. F. J. SIMmondS and Dr. M. A. Ghanı of the CIBC and Dr. M. H. QAZI of Quaid-i-Azam University for critical reading of the manuscript. I am grateful to Dr. L. M. Russell, Dr. M. B. Stoetzel of the USDA, and Dr. P. STARY of the Institute of Entomology, Czechoslavakia Academy of Sciences, Prague and to the specialists of the Commonwealth Institute of Entomology, London for various identifications. I am also thankful to Mrs MeHR-UN-NiSA AHMAD and others for their help during this research.

\section{REFERENCES}

Alam M. M., Hafiz I. A., 1963, Some natural enemics of aphids of Pakistan. Tech. Bull. Commonw. Inst. Biol. Control, 3, 41-44.

Anonyme, 1963. Distribution maps of pests, Toxoptera graminum (Rond.). Map No. 173, C.I.E., 56 Queens Gate, London, S.W. 7. Anonyme, 1965. Distribution maps of pests, Macrosiphum avenae (F.) (graminum (K.by.)). Map No. 204, C.I.E., 56 Queens Gate, London, S.W. 7.

Anonyme, 1971a. Distribution maps of pests, Rhopalosiphum maidis (Fitch). Map No. 67 (revised), C.I.E., 56 Queens Gate, London, S.W. 7.

Anonyme, 1971b. Distribution maps of pests, Rhopalosiphum padi (L.) Map No. 288, C.I.E., 56 Queens Gate, London, S.W. 7.

Archer T. L., Cate R. H., Eikenbary R. D., Starks K. J., 1974. Parasitoids collected from greenbugs and corn leaf aphids in Oklahoma in 1972. Ann. entomol. Soc. Am., 67 (1), 11-14.

Bhatia H. L., Shaffi M., 1933. Life histories of some Indian Syrphidae. Indian J. Agric. Sci., 2 (6), 543-570. (R.A.E. (A) 22 : 241).

Bodenheimer F. S., Swirski E., 1957. The Aphidoidea of the middle east. The Weizmann Science Press of Isracl, Jerusalem, $378 \mathrm{p}$.

Chandler A. E. F., 1966. Some aspects of aphidophagous Syrphidae : 113-115, in "Ecology of aphidophagous insects". Proceedings of a symposium held in Liblice near Prague, September 27-October 1, 1965, Academia, Prague, $360 \mathrm{p}$.

Cherian M. C., 1933. An agromyzid fly predaccous on aphids. Madras Agric. J., 11 (8), 343-344. (R.A.E. (A) 21, 575).
Daniels N. E., Porter K. B., 1956. Greenbug damage to winter wheat as affected by preceding crops. J. econ. Entomol, 49 (4), 600602 .

Das B., 1918. The Aphididae of Lahore. Mem. Indian Museum, 6 (4), 138-274.

George C. J., 1928. South Indian Aphidae. J. \& Proc. Asiat. Soc. Bengal, N.S. 23 (1), 1-12. (R.A.E. (A) 17, 53).

Hamid S., 1979. Some biological, ecological and behavioural studies on the natural balance of graminaceous aphids in Pakistan. $\mathrm{Ph} . \mathrm{D}$. thesis in Quaid-i-Azam University, Islamabad, 1-132.

Jackson H. B., Rogers C. E., Eikenbary R. D., 1971. Colonization and release of Aphelinus asychis an important parasite of the greenbug. J. econ. Entomol., 64 (6), 1435-1438.

Johnson C. G., 1969. Migration and dispersal of insects by flight. Methucn \& Co. Ltd., London, 763 p.

Kapur A. P., 1942. Bionomics of some Coccinellidae, predaceous on aphids and coccids in North India. Indian J. Entomol., 4 (1), 49 66.

Kasi Viswanathan P. R., 1972. New records of Aphidius transcaspicus (Telenga) (Braconidae: Hymenoptera) as a parasite of Rhopalosiphum maidis (Fitch). Indian J. Entomol. 34 (1), 74.

Khan S., Yunus M., 1970. Biology of Syrphus balteatus DeGeer. Pak. J. Zool, 2 (2), 215-217.

Kishan S., Shukla U. S., 1966. Record of a Braconid parasite of Longiunguis sacchari Zhnt. in India (Lysiphlebus S.). Curr. Sci., 35, 602-603. (R.A.E. (A) $57: 363$ ). 
Klostermeyer E. C., 1972. The greenbug in Washington. Circular No. 533, Washington Agricultural Experimental Station, College of Agriculture, Washington State University, $6 \mathrm{p}$.

Lefroy H. M., 1909. Indian insect life. Thacker, Spink and Co., Calcutta.

Mackauer M., Stary P., 1967. World Aphidiidae (Hym. : Ichneumonidae), $195 \mathrm{p}$. in "Index of entomophagous insects" $\mathrm{Ed}$ Delluchi, V. \& G. Remaudiere, Le François, Paris.

Maltais J. B., 1951. The nitrogen contents of different varictics of peas as a factor affecting infestation by Macrosiphum pisi (Kltb.) (Homoptera: Aphididae). Can. Entomol. 83 (2), 29-33.

Mittler T. E., 1973. Aphid polymorphism as effected by diet, 65-75, in "Perspectives of aphid biology" Ed. Lowe, A. D., The Entomological Society of New Zeland (Inc.), Bulletin No. 2, Auckland, N.Z.

Muniappan R., Chada H. L., 1970. Biological control of the greenbug by the spider Phidippus audax. J. econ. Entomol., 63 (5), 1712 .

Narayanan E. S., Subba Rio B. R., Sharma A. K., 1960. A catalogue of the known species of the world belonging to the subfamily Aphidiinae (Hymenoptera: Braconidae). Beitr. Entomol., tome (10), 545-581.

Pruthi H. S., 1942. Report of the Imperial Entomologist. Sci. Rep.
Agric. Res. Inst. New Delhi, 1940-41, 57-63 (R.A.E. (A) 31, 357358).

Puttarudriah M., Channa Basavanna G. P., 1958. Some insect predators of aphids (Aphididae in Mysore). Mysore Agric. J., 32 (34), 158-161.

Rahman K. A., 1940. Important insect predators of India. Proc. Indian Acad. Sci., (B), 12 (3), 167-174.

Sharma P. L., Bhalla O. P., 1964. A survey study of insect pests of economic importance in Himachal Pradesh. Indian J. Entomol., 26 (3) : 318-331.

Subramaniam T. A., 1924. Some Coccinellids of south India. Rep. Proc. 5th Entomol. Meet., Pusa, February 1923: 108-118. (R.A.E. (A) $12: 3831$ ).

Ullah G., 1940. Studies on the Indian Aphididae. 1 - the aphid fauna of Delhi. Indian J. Entomol., 2 (1) : 13-25.

Vereijken P. H., 1979. Feeding and multiplication of three cereal aphids species and their effect on yield of winter wheat. Agriculture Research Reports (Vergl. Landbouwk. Onderz.) 888, Pudoc. Wageningen, $58 \mathrm{p}$.

Walker A. L., Bottrell D. G., Cate J. R., Jr., 1973. Hymenopterous parasites of biotypes greenbug in the high plains of Texas. Ann. entomol. Soc. Am., 66 (1) : 173-176. 